\title{
Musical and Educational Initiatives in Russia in the 2nd Half of the XIX - Early XX Centuries
}

\author{
Elena Polotskaya ${ }^{1,{ }^{*}}$ Karina Yegorova ${ }^{2, a}$
}

\author{
${ }^{1}$ Urals Mussorgsky State Conservatoire, Yekaterinburg, Russia \\ ${ }^{2}$ Children's Music School named after S.S. Prokofiev, Yekaterinburg, Russia \\ aEmail: karina-egorova1994@mail.ru \\ *Corresponding author.Email: eepol@mail.ru
}

\begin{abstract}
The article examines state, public and private initiatives that stimulated the formation and the development of general and special music education in Russia in the 2nd half of the XIX-early XX centuries. The state initiative provided both tenors of music education with organizational, financial and content support of the Imperial court. The public initiative supported the formation of musical and educational departments in various public organizations that contributed to the education of an amateur musician. The state initiative provided both tenors of music education with organizational, financial, and content support of the Imperial court. The public initiative supported the formation of musical and educational departments in various public organizations that contributed to the education of an amateur musician.
\end{abstract}

Keywords: music and educational initiatives, history of Russian music education, general and special music education

\section{INTRODUCTION}

With the advent of the first Russian conservatories the St. Petersburg Conservatory (1862) and the Moscow Conservatory (1866) - two tenors of music education were framed up: general and special. The goal of general music education was to educate enlightened amateur musicians, while the goal of special music education was to educate professional musicians.

The institutionalization of music education was based on the implementation of three main musical and educational initiatives: state, public, and private. The state initiative ensured the Imperial court's support towards organizational, financial, and content aspects of music education. The public initiative, according to the name, stemmed from public organizations that independently choose to include in their structure musical and educational segments contributory to their main occupation. The content of these segments musical and educational segments, concert segments, or the combination of both - depended on an organization's intents, as well as on its financial capabilities. Finally, the private initiative of individuals - specialists in the field of music education - had a form of private music lessons. They were conducted by teachers who would now be called individual entrepreneurs, who earned bread via passing their own knowledge to students. This kind of training was based on the well-known ancient Master-Apprentice principle, it did not provide universal musical knowledge, but it was in demand for solving local tasks of acquiring practical performing skills.

Let's attempt to give a historical assessment of these initiatives in terms of their role in the development of general and special music education.

\section{THE FUNDAMENTAL SIGNIFICANCE OF} THE STATE INITIATIVE FOR THE FORMATION OF SPECIAL AND GENERAL MUSIC EDUCATION

Let's start with special musical education. The need for its formation was largely explained by the "top circles" demand since the cultural development of Russia was the most important point of the state's prestige. The first Russian conservatories, which were formed in the $1860 \mathrm{~s}$ as parts of the structure of the Russian Musical Society (RMS), in 1873 changed their status from public to state along with their parent organization: that year the Russian Musical Society became the Imperial Russian Musical Society (IRMS) and thus received constant material and public support, which also strengthened the position of conservatories. This resulted in a number of social guarantees for professors, privileges for conservatories' graduates, and 
also contributed to the long-term prospects for the development of musical art in Russia ${ }^{1}$.

Already in the 1870s, the first graduates of the St. Petersburg and Moscow Conservatories began to travel around Russia, driven by the desire to raise musical culture. With their active involvement, IRMS created local branches equipped with musical classes in many cities of Russia. As been proved by historical facts, these enthusiasts organized musical educational institutions in Russian provinces in the likeness of a conservatory, as the most familiar for them educational model. Here is a typical excerpt from an advertisement in the newspaper "Yekaterinburg Week" of August 19, 1881: "A graduate of the Imperial Moscow Conservatory course with a diploma of Free artist, S.V. Gilev, starting from September 1, 1881 ... gives lessons in musical subjects according to the program and methods of the Moscow Conservatory"2.

Leaving aside the question of the educational quality, which, of course, varied considerably (depending on the contingent of students), let's pay attention to the fact that all these structures, from music classes to conservatories, were united by such a feature as self-sustainment. These were independent educational institutions whose purpose was to educate students purely musical disciplines. Each student had a direct path to become a professional musician. However, not everyone brought their education to its logical end: some students didn't devote themselves to the profession of a musician but became enlightened amateurs, and the goal of special musical education was replaced by the goal of general ${ }^{3}$.

As for the general musical education itself, it didn't provide for self-sustainment, although clearly formed a system. And again, the state initiative proved to be the most promising in this process: general music education was carried out in state non-musical educational institutions of primary (public schools/schools, city schools), secondary (gymnasiums, women's institutes and cadet corps) and higher education (the Imperial Law School, the Imperial Saint Petersburg University, the Military Medical Academy, and others).

While primary schools and colleges provided no more than primary musical knowledge and skills (mainly related to liturgical singing), music education programs in secondary schools included playing musical instruments, choral singing, and basic music

\footnotetext{
1 The charter of the Music College at the Russian Musical Society. 1861: censorship resolution December 7, 1861. [St. Petersburg, 1861], p. 7. 440$$
\text { Advertisement // Yekaterinburg Week. 1881. August 19. p. }
$$

According to statistics, generally, only a small number of students finished their conservatory education, while the majority of them left the course without completing [1].
}

theory. In higher educational institutions, music classes were optional, but their level spoke for itself: at Saint Petersburg University, for example, existed a mixed choir, a symphony orchestra, and a brass band [2]. According to researchers, in women's institutes, cadet corps, and higher non-musical educational institutions music classes had two tenors: general and in-depth, that claimed to be at the level of prevocational training (using the modern term) [3], [4]. This made it possible for the brightest students to continue their musical education in special musical educational institutions, thereby building bridges between general and special musical education.

So, the state initiative was equally important for both of musical and educational tenors.

\section{THE EFFECTIVENESS OF THE PUBLIC INITIATIVE IN THE SYSTEM OF GENERAL MUSIC EDUCATION}

The public initiative was more in demand in the system of general music education. According to I. F. Petrovskaya's research, the Society for Jewish Folk Music, the Russian Women's Inter-Charitable Association, the Pedagogical Museum, the "Children's World" Society and other organizations were providing music courses and classes in St. Petersburg [5].

Let's review the public initiative effectiveness on the example of the activity of the "Guardianship of Public Sobriety", a state and public structure that arose on the proposal of the Minister of Finance S.Y. Witte in 1895 , and by 1902 already had 760 committees and departments in 63 provinces and 8 regions of the Russian Empire [6]. In 1902, Free Musical Choral Classes were opened under the patronage of Saint Petersburg "Guardianship of Public Sobriety", the purpose of the classes was to organize leisure for commoners to reduce drunkenness [7]. It would seem that it did not require special efforts to develop educational programs to achieve this - the teaching of the basics of musical art seemed to be enough. However, even these classes had the division into preparatory and special courses. The classes' program included secular and liturgical singing, playing Russian folk instruments, reading music, and basic music theory. From the second half of the 1900 s, piano playing and music history were introduced. They were followed by harmony, solo singing, playing the violin, mandolin, zither, later by the guitar. The choir and the Great Russian orchestra consisted of the special courses students who participated in free and paid concerts. And the ten-year existence of the classes was marked by the production of the M. I. Glinka's opera "Life for the Tsar" in an abridged version for folk theaters. Thus, the level of education in the classes could qualify for prevocational training of students, if not for the specifics of the contingent of students formed from 
adults, usually the poor, who already had some kind of occupation.

\section{THE ROLE OF THE PRIVATE INITIATIVE IN THE EDUCATION OF A PROFESSIONAL MUSICIAN}

The private initiative provided general musical education, similar to the public initiative. Most often, private music lessons were in demand in noble families, who considered home-teaching music education as an integral part of the upbringing of the younger generation. In such families, the greatest "demand" was for academic singing lessons, playing instruments (piano, violin, cello, flute), and music theory.

It happened that after some time a student outgrew his teacher in the mastering of musical art. A striking example of this is the first music teacher of P. I. Tchaikovsky, Maria Markovna Palchikova (married name Loginova), who didn't have a special musical education, but taught a five-year-old boy the basics of playing the piano (or maybe even taught him the basics of composition, because she tried to write plays and even send them as a gift to the Empress) and remained his favorite teacher forever [8]. Similar episodes can be found in the biography of many famous musicians, which indicates a persistent tradition of home-teaching music education in the urban estates families.

However, hiring private music teachers not always occurred due to this tradition. Sometimes the goal of private lessons was to enroll a student into a special musical educational institution, most often - in a conservatory. In this case, a teacher firstly taught music as a future occupation, and secondly, was obliged to follow the criteria of professional music schools [9]. Thus, student's training went beyond General music education and could be equated to prevocational education.

The effectiveness of the private initiative in the educational process, first of all, depended on the teacher's qualifications. Private music lessons were given by graduates of European conservatories, such as A. S. Famintsyn, E. Langer, or K. J. Lutsch who graduated from the Leipzig Conservatoire. But there were also those who did not have a documented special musical education and, from this point of view, were not professionals. However, having a musical talent and a solid pedagogical experience, such a teacher's teaching level was not inferior to a certified specialist's one.

Outstanding musicians of the XIX century were engaged in private teaching practice. According to A. I. Puzyrevsky and L. A. Sacchetti - the St. Petersburg Conservatory historiographers - the Conservatory was open after the rise of a private initiative in the 1850s: "in St. Petersburg at this time there was a significant increase in demand ... for teachers in all branches of musical art, among which you can see names of outstanding music teachers who formed many Russian musicians. Among these the Maurer violinists (father and son), G. Venyavsky, Albrecht and other pianists, who need to be mentioned: A. A. Gerke, A. Henselt, singers and singers: Ms. Nissen-Saloman, Lodiiy, Piccioli, some opera singers, cellist K. B. Schuberth, etc. There were those who wanted to study the theory of composition, which was taught by A. Maurer, I. K. Gunke, and N. I. Zaremba" [10]. Classes tough by such authorities had a common characteristic: high quality of education. The knowledge received by students was practically comparable to professional knowledge.

We will reveal this thesis by referring to the figure of Nikolai Ivanovich Zaremba (1821-1879). A favorite student of the German musician-theorist A. B. Marx, who privately tough Zaremba composition theory in 1853-1854 in Berlin, Zaremba became the first professor of music theory in the history of Russian conservatory education. Since the opening of the Saint Petersburg Conservatory and during his directorship (1862-1871) his teaching was framed by periods of exclusively private teaching practice in musictheoretical subjects. The first period ( 2 nd half of the 1850s) was marked by two historically important moments: Zaremba was the first in the Russian musical education of the XIX century to teach theoretical subjects in Russian and the first to best fully introduce Russian musicians to Marx's theory of composition, bringing its propositions both into private and conservatory lessons [11].

The second period of Zaremba's private pedagogical initiative began on his return from Germany, where he lived from 1871 to 1873 . A testament to Nikolai Ivanovich's high pedagogical professionalism is a notebook called "Forms"4, which is kept in the archive of the Saint Petersburg Museum of Theater and Music Art and belongs to the outstanding pianist and conductor Vasily Safonov, one of the last, or perhaps the last, private Zaremba's student. The notebook contains Safonov's lecture notes and completed Homeworks, which show how much knowledge and practical skills in modeling musical forms he gained in a very short period of education (from the end of 1877 till May 1878). There are both polyphonic forms from chorale processing to Fuga and homophonic forms from period to song forms [12]. Giving Safonov tasks of modeling these forms, Zaremba, in fact, taught him composition $^{5}$. 30. No. 9

4 St. Petersburg State Museum of Theater and Music. Fund

Today the success of his educating is evidenced by the fact that a number of student works performed under the guidance of Zaremba from the course "Form" were included in the collection of Safonov's piano pieces, which were published in 2020 [13]. 
We emphasize that the development of the course "Forms" preceded Safonov's admission to the St. Petersburg Conservatory in 1879. This fact is more important than just a fact from Vasily Safonov's biography. It points to another characteristic of private initiative that is no less important than professionalism - teacher's pedagogical talent. Zaremba certainly had one $^{6}$.

Returning to the private initiative on the scale of Russian music education, we come to the following conclusions. The main area of application of the private initiative was general music education. While the purpose of private lessons was to prepare young people for admission to a special musical institution, the private initiative revealed a concomitant goal that was prevocational education. The main criterion that determined the quality of a private musical and educational initiative was a teacher's professionalism.

\section{CONCLUSION}

All the musical and educational initiatives demonstrated the goal-oriented interest of Russian society in creating a system of general and special music education. All of them had a cross-wind nature of interaction: state, public, and private initiatives, that were aimed at educating enlightened music lovers by means of in-home music education or non-musical educational institutions, also worked on the formation of special music education. If an amateur musician was raised by a professional, his level of education reached a prevocational level.

The state initiative also pursued two goals: enlightened amateurishness accompanied the education of a professional musician in those numerous cases when a student of music schools or colleges either did not enter a conservatory, or did not finish education, or, even after graduation, did not choose the path of a professional musician.

Thus, the considered period is a time of active mutual inter influence of general and special musical education often accompanied by merging goals of both tenors. Meanwhile, each tenor needed independent spheres of functioning as it developed. What initiatives could contribute more to the separation of general and special education in the Russian Empire?

\footnotetext{
6 From the memoirs of Safonov's daughter Maria Safonova: "In the person of professor Zaremba, Vasily found a powerful ally who highly valued the musical abilities of his student and was convinced that the true vocation of this young man is music. Zaremba, as father later told us, had an extraordinary power of persuasion - in any conversation, his words had special weight. This was also the case of a conversation with Ilya Ivanovich: Zaremba managed to convince the colonel that if his son would be forbidden to devote himself to music, ... he would be the most unhappy person. Ilya Ivanovich, beinga loving father, realized that there was no other optionbut to bless his son's choice..." [14].
}

As mentioned above, the state initiative was particularly effective for Russian conservatories: it was with the support of the Imperial government that the Russian conservatories adopted the music and education model of the Leipzig Conservatory. Largely due to this highest approval, the structure and content of the educational process in the conservatory began to convey to musical classes, schools, and colleges, which by the end of the XIX - the beginning of the XX century began to spread in Russia. There was some kind of the "Matryoshka effect" when, along with the formally existing chain of prevocational musical education institutions in the country (music schools and colleges), each musical educational institution was conceived of as a smaller copy of a conservatory. This situation was well described by P. I. Tchaikovsky in an interview to the "Petersburg life" magazine in 1892, when he compared Russian conservatories with universities, "which would exist in a country without lower and secondary educational institutions " [15]. It was still necessary to unify primary educational structures, to define a musical and educational "standard" for music schools and colleges separately, and to develop musical and pedagogical teaching technologies aimed either at children or youth, i.e., to "arrange ... schools that would compare gymnasiums" [15]. According to the composer, it was also necessary "for the obligatory teaching of choral singing to be widely spread and strengthened in all the lower educational institutions of our fatherland" [15].

Ranking the initiatives described in the second half of the XIX - early XX centuries by their significance on a national scale, we agree with Tchaikovsky. To the question: "... can all this be accomplished by means of private initiative solely?", he replied: "Hardly. It seems to me that it would be the greatest weal for Russian art if the government took into its own hands the care of all its branches; only the government has as much money, strength, and power as this great work requires" [15].

\section{References}

[1] M. A. Govorukhina, compiler, "Students of P. I. Tchaikovsky's theoretical classes at the Moscow Conservatory", Yekaterinburg: Urals Mussorgsky State Conservatoire, 2014, pp. 82.

[2] I. F. Petrovskaya, "Musical Petersburg, 1801-1917: an Encyclopedic dictionary-research". Saint Petersburg: Kompozitor Saint Petersburg, 2010. Book 2: M-Ya, volume 11, pp. 399-405.

[3] V. I. Adishchev, "Music education in women's institutes and cadet corps of Russia in the second half of the XIX-early XX centuries: theory, concepts, practice: monograph", Moscow: Music, 2007, p. 344.

[4] I. F. Petrovskaya, "Music education and musical public organizations in St. Petersburg. 1801-1917 it is: an encyclopedia". Saint Petersburg: publishing house " Petrovsky Fund", 1999, pp. 75-76, p. 291. 
[5] I. F. Petrovskaya, "Musical Petersburg, 1801-1917: an Encyclopedic dictionary-research", cited edition, p. 75.

[6] Guardianship of Public Sobriety // Big Russian encyclopedia [Electronic resource]: https://bigenc.ru/domestic_history/text/3158556 (accessed: 29.06.2020).

[7] I. F. Petrovskaya, "Music education and musical public organizations in St. Petersburg. 1801-1917 it is: an encyclopedia", cited edition, pp. 44-46.

[8] E. E. Polotskaya, "P. I. Tchaikovsky and the formation of composer's education in Russia": dissertation for ... a Doctor of Arts degree, Moscow, 2009, pp. 98-99.

[9] A. C. Nazarova, "Tutor as a phenomenon of national musical culture": Thesis work. Yekaterinburg: Urals Mussorgsky State Conservatoire. Yekaterinburg, 2020, p. 76.

[10] A. I. Puzyrevsky and L. A. Sacchetti, compilers, "An essay on the fiftieth anniversary of the St. Petersburg Conservatory". Saint Petersburg: Glazunov printing House, 1912, pp. 5-6.

[11] E. Polockaja, "The most important is coherence and consistency. Nikolaj Zaremba, Tchaikovsky's teacher", http://www.tschaikowsky-gesellschaft.de/mitteilungenonline/2018-07-27-Zaremba-Polockaja-Mitt-Online.pdf

[12] E. E. Polotskaya, "From the history of musical and theoretical education in Russia (according to V. I. Safonov's student notebooks)" // "Work and hope...". Vasily Safonov: new materials and research". Moscow; Saint Petersburg: Center for humanitarian initiatives, 2017, pp. 576-590.

[13] V. I. Safonov, Works for piano / compilers E. E. Polotskaya, A. M. Merkulov; edited by I. N. Vanovskaya, Tambov: the memorial estate of S. V. Rachmaninoff "Ivanovka", 2020, pp. 47.

[14] L. L. Tumarinson, B. M. Rosenfeld, compilers, "Chronicle of the life and work of V. I. Safonov", Moscow: "Bely Bereg", 2009, p. 51.

[15] P. I. Tchaikovsky, Complete works, vol. II: "Literary works and correspondence", Moscow: Muzgiz, 1953, p. 373. 